\title{
HBV Infection in Italian and Non-Italian Patients in Northern Italy
}

\author{
Massimo De Paschale ${ }^{1^{*}}$, Maria Teresa Manco ${ }^{1}$, Luisa Belvisi ${ }^{1}$, \\ Carlo Magnani ${ }^{2}$, Tiziana Re $^{2}$, Paolo Viganò ${ }^{2}$, Sara Biagiotti ${ }^{3}$, \\ Francesca Capelli ${ }^{3}$, Antonino Mazzone ${ }^{3}$, Maria Pia Baldacci ${ }^{4}$, \\ Aldo Ferrara $^{4}$, Anna Lisa Neri ${ }^{5}$, Carlo Maria Guastoni ${ }^{5}$, \\ Riccardo Armando Bonazzina ${ }^{6}$, Bruno Brando ${ }^{7}$ and Pierangelo Clerici ${ }^{1}$ \\ ${ }^{1}$ Microbiology Unit, Hospital of Legnano, Legnano (Milan), Italy. \\ ${ }^{2}$ Infectious Diseases Department, Hospital of Legnano, Legnano (Milan), Italy. \\ ${ }^{3}$ Division of Internal Medicine Hospital of Legnano, Legnano (Milan), Italy. \\ ${ }^{4}$ Gastroenterology and Digestive Endoscopy Unit, Hospital of Legnano, Legnano (Milan), \\ Italy. \\ ${ }^{5}$ Nephrology Unit, Hospital of Legnano, Legnano (Milan), Italy. \\ ${ }^{6}$ Occupational Medicine Unit, Hospital of Legnano, Legnano (Milan), Italy. \\ ${ }^{7}$ Blood Transfusion Centre, Hospital of Legnano, Legnano (Milan), Italy.
}

\section{Authors' contributions}

This work was carried out in collaboration with all authors. Author MDP designed the study and wrote the manuscript. All authors supervised the study, searched and analyzed the data and approved the final manuscript. All authors read and approved the final manuscript.

Research Article

Received 6 ${ }^{\text {th }}$ August 2012

Accepted $10^{\text {th }}$ October 2012 Published $8^{\text {th }}$ December 2012

\section{ABSTRACT}

Aims: The introduction of HBV vaccination in Italy has reduced the incidence and prevalence of HBV infection. However, increasing immigration from countries in which HBV is endemic has led to a wave of new HBsAg-positive subjects and their clinical impact needs evaluation. We compared the serological, clinical and epidemiological data relating to Italian and non-Italian subjects referred to a hospital in Northern Italy. Study Design: We retrospectively analysed the laboratory and clinical records of 488 subjects, including $107(21.9 \%)$ non-Italians, in order to find data concerning clinical diagnoses, possible routes of infection, anti-HCV and anti-HDV antibodies.

Results: The differences in gender distribution and mean age between the non-Italian 
and Italian patients were statistically significant $(p<.001)$. There were no significant differences in the prevalence of anti-HCV $(2.9 \%$ vs $4.9 \%, \mathrm{p}=.86)$ or anti-HDV $(4.7 \%$ vs $5.0 \%, \mathrm{p}=.89$ ) co-infection, or the presence of $\mathrm{HBeAg}$ in chronic infection. There were no differences in the rates of acute $(3.3 \%$ vs $5.1 \% ; p=.68)$ or chronic infections $(96.7 \%$ vs $94.9 \% ; p=.68)$ infections, but there were statistically significant differences $(p<.001)$ in the rates of prevalent (54.5\% vs $85.3 \%$ ) and incident cases (45.5\% vs $14.7 \%)$. The differences in the rates of asymptomatic $(70.6 \%$ vs $34.9 \%)$ and symptomatic patients $(29.4 \%$ vs $65.1 \%)$ were also statistically significant $(p<.001)$. The only significant differences in terms of risk factors related to transfusions ( $0 \%$ vs $6.8 \% ; p=.04)$, and vertical/perinatal transmission $(44.1 \%$ vs $6.8 \%$; $p<.001)$.

Conclusion: The non-Italian HBsAg-positive subjects were mainly women and younger than their Italian counterparts, and had a recent diagnosis. They were predominantly asymptomatic and probably considered themselves healthy and fit to emigrate. Perinatal transmission among non-Italians is still an important risk factor that reflects the epidemiological situation of their countries of origin.

Keywords: HBV; Italy; foreign origin; hepatitis.

\section{INTRODUCTION}

Infection with hepatitis B virus (HBV) is one of the major causes of human morbidity and mortality, and may lead to sub-clinical or asymtomatic infection, acute self-limited hepatitis, or fulminant hepatitis requiring liver transplantation. Infected HBV patients may also develop chronic infection, which can lead to cirrhosis or hepatocellular carcinoma. It is estimated that at least two billion people are infected with HBV worldwide, and that more than 350 million are chronic carriers of the virus. There are 4.5 million newly infected patients each year, 15$40 \%$ of whom develop cirrhosis, various liver diseases and hepatocellular carcinoma. About $500,000-700,000$ people die of acute hepatitis or the chronic sequelae of HBV infection every year [1-5].

HBV is ubiquitous, but the prevalence of infection varies from a seroprevalence of HBsAg of $<2 \%$ (in Western Europe, North and South America, except for some Brazilian and Peruvian regions) to one of $\geq 8 \%$ (in highly endemic regions such as Africa and parts of Asia) [6].

In the 1970 s and 1980s, Italy was an intermediately endemic country with about two million HBsAg carriers (about 3.5\% of the population), albeit with differences between the north (about $0.5 \%$ ) and south (>5\%) [7-10]. However, subsequently, the epidemiology of HBV changed for various reasons: improved socio-economic conditions, better hygiene standards (the screening of blood units and blood components, disinfection and sterilisation of medical and surgical instruments, the introduction and use of disposable aids, and environmental and hospital education campaigns), smaller-sized families, and HIV educational campaigns. In 1983, the selective vaccination of people at risk was introduced on a regional basis for intravenous drug users (IVDUs), male homosexuals, subjects with multiple sexual partners, the partners of HBsAg carriers, hemophiliacs and the newborns of HBsAg-positive mothers. In 1991 (Law 165 of 27 May 1991), a campaign of compulsory vaccination was started for all children aged 12 years (during the first 12 years of the law coming into force) and infants in the first year of life, in addition to maintaining the selective vaccination of people at risk [11, 12]. As a result of all of these factors, the incidence of acute hepatitis and the prevalence of HBsAg carriers greatly decreased. 
According to data from the National Surveillance System for Acute Viral Hepatitis (SEIEVA), the incidence of acute hepatitis B fell from 10.4 cases per 100,000 inhabitants in 1987 [13] to 1.3 in 2005 [14] and HBV became less endemic in Italy insofar as the prevalence of HBsAg carriers was estimated to be $<2 \%[15,16]$. The sexual route (unsafe sexual practices) is the most important risk factor, but intravenous drug abuse (IVDA), nosocomial exposure (transfusions of blood units or blood components, invasive surgical procedures or dental treatments), co-habitation with HBsAg carriers and cosmetic treatments (tattooing, piercing, acupuncture, shaving, manicure/pedicure) also play an important role [14]. The percentage of acute hepatitis B patients with a history of surgery, transfusions or co-habitation with chronic carriers has remained constant over time, whereas those with a history of IVDA have decreased [14].

However, increasing immigration to Italy in recent years has led to the arrival of a growing number of patients from countries in which HBV is endemic. It has been estimated that there are now about 3.8 million immigrants in Italy, about $6 \%$ of the population [17] and the epidemiology of HBV is rapidly changing. According to SEIEVA, in 2004-2005, $14 \%$ of the reported cases of acute hepatitis involved patients from Eastern Europe, Asia or Africa [14]. In a previous study of our area [18], the prevalence of HBsAg was estimated to be $2.1 \%$ with a statistically significant difference between Italian (1.8\%) and non-Italian subjects (6.5\%).

The clinical impact can also be relevant depending on the circulating virus strain. Eight genotypes of HBV have so far been described, with differences in their geographical distribution, clinical impact, and responsiveness to anti-viral treatment [19-28]. HBV genotype $D$ has been responsible for nearly $95 \%$ of the cases of acute and chronic hepatitis $B$ in Italy [20]. Furthermore, a variety of mutations in the HBV genome can lead to different clinical diseases. During the typical course of HBV infection, an HBeAg-positive phase (with high serum HDV DNA levels) is followed by a process of seroconversion, with the loss of $\mathrm{HBeAg}$, the appearance of anti-HBe, and a decline in HBV DNA. In a variant form that decreases or abolishes the production of $\mathrm{HBeAg}$, patients develop anti-HBe with active HBV DNA replication and consequent liver damage [29]. This variant form has a different geographical distribution, and is more prevalent in the Mediterranean area than in Asia, USA or Northern Europe [30].

The aim of this study was to compare the serological, clinical and epidemiological data of Italian and non-Italian patients referred to a hospital in Northern Italy.

\section{MATERIALS AND METHODS}

We retrospectively examined the laboratory and clinical records of all HBsAg-positive subjects tested at our hospital between 1 January 2007 and 31 December 2008 (with enzyme-linked immunosorbent assay: Hepanostika HBsAg Ultra and Hepanostika HBsAg Ultra Confirmatory, BioMérieux, Boxtel, The Netherlands): 488 subjects, 283 males (58.0\%) and 205 females (42.0\%) whose mean age was 51.4 years (range 1-93). Two hundred and forty-five (50.2\%) were in-patients admitted to the departments of Infectious Diseases, Internal Medicine, Gastroenterology and Nephrology; 63(12.9\%) were in-patients admitted to surgical or other medical units; $163(33.4 \%)$ were outpatients referred by their General Practitioners for a clinical check-up (130: 26.6\%) or HBsAg screening during pregnancy (33 patients: $6.8 \%$ ); eight (1.6\%) were from the Occupational Medicine Unit supervising hospital staff; and nine (1.8\%) from the Blood Transfusion Centre (pre-transfusion screening or testing the suitability of candidate donors). 
Clinical and laboratory files on paper or computer were retrospectively consulted in order to retrieve information concerning searches for anti-HCV, HBeAg/anti-HBe and anti-HDV antibodies (respectively searched with enzyme-linked immunosorbent assay: HCV 3.0 ELISA Test, ORTHO, Raritan, USA; ETI-EBK PLUS, ETI-AB-EBK PLUS and ETI-ABDELTAK-2, DiaSorin, Saluggia, Italy), the type of infection (chronic or acute), the clinical diagnosis, and possible risk factors. Whenever possible, and as previously described in the literature [31-33], the subjects were divided into "incident cases" (those diagnosed as having chronic hepatitis for the first time during the study) and "prevalent cases" (those diagnosed as having chronic hepatitis before the study period). The clinical diagnosis was based on liver biopsy data if a biopsy had been performed; if not, the diagnosis of chronic hepatitis was based on the presence of fluctuating or persistently ( $>6$ months) high aminotransferase levels (upper normal limit: $40 \mathrm{U} / \mathrm{L}$ for aspartate aminotransferase [AST, determined for both Italian and non-Italian subjects with IFCC/p-5-P COBAS method, Roche, Mannheim, Germany] and $45 \mathrm{U} / \mathrm{L}$ for alanine aminotransferase [ALT, determined with IFCC/p-5-P COBAS method, Roche, Mannheim, Germany]) in the absence of clinical, biochemical or ultrasound markers of cirrhosis; the diagnosis of cirrhosis was based on the presence of clinical, biochemical or ultrasound signs [34]; and the diagnosis of hepatocellular carcinoma was based on two imaging techniques showing a typical vascular pattern [35]. The patients included in the group of inactive HBsAg carriers had to be $\mathrm{HBeAg}$ negative and anti-HBe positive, and have persistently normal transaminase (ALT and AST) levels, and HBV DNA levels of $<2000 \mathrm{IU} / \mathrm{mL}$ (COBAS TaqMan HBV test, Roche, Mannheim, Germany) [36]. The diagnosis of acute HBV hepatitis was based on clinical, biochemical, and serological criteria, including the occurrence of an acute illness compatible with hepatitis together with an increase in serum ALT levels ( $>25$ times the upper normal limit) and the presence of $\lg M$ hepatitis B core antibody (ETI-CORE-IGMK PLUS, DiaSorin, Saluggia, Italy) and HBsAg. Methods and kits for virological, biochemical and clinical markers determinations are the same for both Italian and non-Italian subjects. The findings were statistically analysed using the $x^{2}$ test, Fisher's exact test and Student's $t$ test. An adjustment for age and gender was made using logistic regression by MacAnova where possible.

\section{RESULTS}

Of the 488 patients, $381(78.1 \%$ ) were Italians and $107(21.9 \%)$ non-Italians (50 from Eastern Europe, 23 from Sub-Saharan Africa, 13 from China and the Far East, 10 from the Middle East and the Maghreb, six from the Indian sub-continent, three from Latin America, and two from Western Europe/North America). Table 1 shows their gender distribution and mean age, both of which were different between the two groups as a whole. Stratification by geographic area of origin revealed a significant difference in gender distribution only between the Italians and the subjects from China/Far East $(p=.001)$ and Eastern Europe $(p<.001)$.

Anti-HCV and anti-HDV antibodies were sought in respectively 452 and 488 subjects (Table 2). There were no significant differences between the non-Italian (taken together) and Italian patients in the prevalence of these antibodies, also stratifying by geographic area of origin or adjusting for age and gender. 
Table 1. Personal data relating to non-Italian and Italian HBsAg-positive patients

\begin{tabular}{|c|c|c|c|c|c|c|c|}
\hline & \multicolumn{2}{|c|}{ Non-talian } & \multicolumn{2}{|l|}{ Italian } & \multirow[t]{2}{*}{$p$} & \multicolumn{2}{|c|}{ Total } \\
\hline & $\mathbf{N}$ & $\%$ & $\mathbf{N}$ & $\%$ & & $\mathbf{N}$ & $\%$ \\
\hline Number of patients & 107 & 21.9 & 381 & 78.1 & & 488 & \\
\hline Male & 41 & 38.3 & 242 & 63.5 & $<.001$ & 283 & 58.0 \\
\hline $\begin{array}{l}\text { Female } \\
\text { Mean age in years } \\
\text { (range) }\end{array}$ & $\begin{array}{l}66 \\
32.2 \\
(1-59)\end{array}$ & 61.7 & $\begin{array}{l}139 \\
56.9 \\
(23-93\end{array}$ & 36.5 & $\begin{array}{l}<.001 \\
<.001\end{array}$ & 205 & 42.0 \\
\hline
\end{tabular}

Table 2. Serological data relating to non-Italian and Italian HBsAg-positive patients adjusting for age and gender

\begin{tabular}{|c|c|c|c|c|c|c|c|}
\hline & \multicolumn{2}{|c|}{ Non-Italian } & \multicolumn{2}{|l|}{ Italian } & \multirow[t]{2}{*}{ p } & \multicolumn{2}{|l|}{ Total } \\
\hline & $\mathbf{N}$ & $\begin{array}{l}\% \\
(95 \% \mathrm{Cl})\end{array}$ & $\mathbf{N}$ & $\begin{array}{l}\% \\
(95 \% \mathrm{Cl})\end{array}$ & & $\mathbf{N}$ & $\begin{array}{l}\% \\
(95 \% \mathrm{Cl})\end{array}$ \\
\hline $\begin{array}{l}\text { Anti-HCV } \\
\text { positive }\end{array}$ & $3 / 102$ & $\begin{array}{l}2.9 \\
(0.00-6.16)\end{array}$ & $17 / 350$ & $\begin{array}{l}4.9 \\
(2.64-7.16)\end{array}$ & .86 & $20 / 452$ & $\begin{array}{l}4.4 \\
(2.51-6.29)\end{array}$ \\
\hline $\begin{array}{l}\text { Anti-HDV } \\
\text { positive }\end{array}$ & $5 / 107$ & $\begin{array}{l}4.7 \\
(0.69-8.71)\end{array}$ & $19 / 381$ & $\begin{array}{l}5.0 \\
(2.81-7.19)\end{array}$ & .89 & $24 / 488$ & $\begin{array}{l}4.9 \\
(2.98-6.81)\end{array}$ \\
\hline
\end{tabular}

$95 \% \mathrm{Cl}=95 \%$ Confidence Interval

HBV infection data were available for 385 patients, 18 of whom had acute and 367 chronic infections (Table 3). There were no statistically significant between the Italian and non-Italian subjects (even when stratified by geographic area or adjusting for age and gender). In the 366 of 367 patients with chronic infection, it was possible to identify 285 prevalent cases and 81 incident cases, with a statistically significant difference between the Italian and non-Italian patients (adjusting for age and gender) (Table 3). Stratification by geographic area of origin showed that statistically significant difference was in the case of the patients from Eastern Europe $(51.2 \%$, 95\%Cl:36.26-66.14 of prevalent cases and $48.8 \%, 95 \% \mathrm{Cl}: 33.86-63.74$ of incident cases, $\mathrm{p}<.001)$, China/Far East $(27.3 \%, 95 \% \mathrm{Cl}: 0.97-53.63$ of prevalent and $72.7 \%$, $95 \% \mathrm{Cl}$ : $46.37-99.02$ of incident cases; $\mathrm{p}<.001 \%)$ and Indian subcontinent $(25.0 \%, 95 \% \mathrm{Cl}$ : 0.00-67.43 of prevalent and $75.0 \%, 95 \% \mathrm{Cl}$ : $32.56-100$ of incident cases, $\mathrm{p}=.01$ ). The clinical diagnosis was known in 317 patients, and there was a statistically significant difference between the Italian and non-Italian patients (adjusting for age and gender) (Table 3).

Stratification by geographic area of origin showed that the prevalence of asymptomatic forms was significantly higher $(p<.001)$ in the patient from sub-Saharan Africa $(75.0 \%, 95 \% \mathrm{Cl}$ : 56.02-93.98), China/Far East (90.9\%, 95\%Cl: 73.90-100) and Eastern Europe $(68.3 \%$, $95 \% \mathrm{Cl}: 54.06-82.54)$ than in the Italian subjects.

The only significant differences in known risk factors concerned transfusions (but not when stratified by geographic area of origin) and vertical/perinatal transmission $(76.5 \% 95 \% \mathrm{Cl}$ : 56.34-96.66 of the sub-Saharan subjects, $\mathrm{p}<.001,28.0 \%, 95 \% \mathrm{Cl}: 10.40-45.60$; of the East Europeans, $\mathrm{p}=.003,66.7 \%, 95 \% \mathrm{Cl}: 13.37-100$ of Indian subcontinent subjects, $\mathrm{p}=.02$ and $37.5 \%, 95 \% \mathrm{Cl}$ : 3.95-71.05 of Middle East/Maghreb subjects, $\mathrm{p}=.02$ (Table 4).

The results of searches for $\mathrm{HBeAg}$ and anti-HBe were available for 351 patients, 74 of whom were incident cases. There were no statistically significant differences between the Italian and the total non-Italian patients (adjusting for age and gender) (Table 5). 
Table 3. Type of infection and clinical diagnosis in non-Italian and Italian HBsAg-positive patients adjusting for age and gender

\begin{tabular}{|c|c|c|c|c|c|c|c|}
\hline & \multicolumn{2}{|c|}{ Non-Italian } & \multicolumn{2}{|l|}{ Italian } & \multirow[t]{2}{*}{$\mathbf{p}$} & \multicolumn{2}{|l|}{ Total } \\
\hline & $\mathbf{N}$ & $\begin{array}{l}\% \\
(95 \% \mathrm{Cl})\end{array}$ & $\mathbf{N}$ & $\begin{array}{l}\% \\
(95 \% \mathrm{Cl})\end{array}$ & & $\mathbf{N}$ & $\begin{array}{l}\% \\
(95 \% \mathrm{Cl})\end{array}$ \\
\hline \multicolumn{8}{|l|}{ Infection } \\
\hline acute & $3 / 92$ & $\begin{array}{l}3.3 \\
(0.00-6.95)\end{array}$ & $15 / 293$ & $\begin{array}{l}5.1 \\
(2.58-7.62)\end{array}$ & .68 & $18 / 385$ & $\begin{array}{l}4.7 \\
(2.59-6.81)\end{array}$ \\
\hline chronic & $89 / 92$ & $\begin{array}{l}96.7 \\
(93.05-100)\end{array}$ & $278 / 293$ & $\begin{array}{l}94.9 \\
(92.38-97.42)\end{array}$ & .68 & $367 / 385$ & $\begin{array}{l}95.3 \\
(93.19-97.41)\end{array}$ \\
\hline \multicolumn{8}{|l|}{ Cases } \\
\hline prevalent & $48 / 88$ & $\begin{array}{l}54.5 \\
(44.10-64.90)\end{array}$ & $237 / 278$ & $\begin{array}{l}85.3 \\
(81.14-89.46)\end{array}$ & $<.001$ & $285 / 366$ & $\begin{array}{l}77.9 \\
(73.65-82.15)\end{array}$ \\
\hline incident & $40 / 88$ & $\begin{array}{l}45.5 \\
35.10-55.90)\end{array}$ & $41 / 278$ & $\begin{array}{l}14.7 \\
(10.54-18.86)\end{array}$ & $<.001$ & $81 / 366$ & $\begin{array}{l}22.1 \\
(17.85-26.35)\end{array}$ \\
\hline \multicolumn{8}{|l|}{ Clinical symptons } \\
\hline asymptomatic & $60 / 85$ & $\begin{array}{l}70.6 \\
(60.91-80.29)\end{array}$ & $81 / 232$ & $\begin{array}{l}34.9 \\
(28.77-41.03)\end{array}$ & $<.001$ & $141 / 317$ & $\begin{array}{l}44.5 \\
(39.03-49.97)\end{array}$ \\
\hline symptomatic & $25 / 85$ & $\begin{array}{l}29.4 \\
(19.71-39.09)\end{array}$ & $151 / 232$ & $\begin{array}{l}65.1 \\
(58.97-71.23)\end{array}$ & $<.001$ & $176 / 317$ & $\begin{array}{l}55.5 \\
(50.03-60.97)\end{array}$ \\
\hline (Chronic hepatitis) & $19 / 85$ & $\begin{array}{l}22.4 \\
(13.54-31.26)\end{array}$ & $101 / 232$ & $\begin{array}{l}43.5 \\
(37.12-49.88)\end{array}$ & $<.001$ & $120 / 317$ & $\begin{array}{l}37.9 \\
(32.56-43.24)\end{array}$ \\
\hline (cirrhosis) & $6 / 85$ & $\begin{array}{l}7.1 \\
(1.64-12.56)\end{array}$ & $43 / 232$ & $\begin{array}{l}18.5 \\
(13.50-23.50)\end{array}$ & .95 & $49 / 317$ & $\begin{array}{l}15.5 \\
(11.52-19.48)\end{array}$ \\
\hline (hepatocellular carcinoma) & $0 / 85$ & $\begin{array}{l}0.0 \\
(0.00-0.00)\end{array}$ & 7/232 & $\begin{array}{l}3.1 \\
(0.87-5.33)\end{array}$ & $.19^{*}$ & $7 / 317$ & $\begin{array}{l}2.2 \\
(0.58-3.81)\end{array}$ \\
\hline
\end{tabular}


Table 4. Risk factor in non-Italian and Italian HBsAg-positive patients adjusting for age and gender

\begin{tabular}{|c|c|c|c|c|c|c|c|}
\hline \multirow[t]{2}{*}{ Risk factors } & \multicolumn{2}{|c|}{ Non-Italian } & \multicolumn{2}{|l|}{ Italian } & \multirow[t]{2}{*}{$\mathbf{p}$} & \multicolumn{2}{|l|}{ Total } \\
\hline & $\mathbf{N}$ & $\begin{array}{l}\% \\
(95 \% \mathrm{Cl})\end{array}$ & $\mathbf{N}$ & $\begin{array}{l}\% \\
(95 \% \mathrm{Cl})\end{array}$ & & $\mathbf{N}$ & $\begin{array}{l}\% \\
(95 \% \mathrm{Cl})\end{array}$ \\
\hline IVDA & $2 / 59$ & $\begin{array}{l}3.4 \\
80.00-8.02)\end{array}$ & $18 / 192$ & $\begin{array}{l}9.4 \\
(5.27-13.53)\end{array}$ & .15 & $20 / 251$ & $\begin{array}{l}8.0 \\
(4.64-11.36)\end{array}$ \\
\hline Community acquired infection & $20 / 59$ & $\begin{array}{l}33.9 \\
(21.82-45.98)\end{array}$ & 103/192 & $\begin{array}{l}53.6 \\
(46.55-60.65)\end{array}$ & .93 & $123 / 251$ & $\begin{array}{l}49.0 \\
(42.82-55.18)\end{array}$ \\
\hline Sexual contact & $8 / 59$ & $\begin{array}{l}13.6 \\
(4.85-22.35)\end{array}$ & $24 / 192$ & $\begin{array}{l}12.5 \\
(7.82-17.18)\end{array}$ & .71 & $32 / 251$ & $\begin{array}{l}12.7 \\
(8.58-16.82)\end{array}$ \\
\hline Family contacts & $3 / 59$ & $\begin{array}{l}5.1 \\
(0.00-10.71)\end{array}$ & $15 / 192$ & $\begin{array}{l}7.8 \\
(4.00-11.59)\end{array}$ & .94 & $18 / 251$ & $\begin{array}{l}7.2 \\
(4.00-10.40)\end{array}$ \\
\hline Vertical/perinatal transmission & $26 / 59$ & $\begin{array}{l}44.1 \\
(31.43-56.77)\end{array}$ & 13/192 & $\begin{array}{l}6.8 \\
(3.24-10.36)\end{array}$ & $<.001$ & $39 / 251$ & $\begin{array}{l}15.5 \\
(11.02-19.98)\end{array}$ \\
\hline Transfusions & $0 / 59$ & $\begin{array}{l}0.0 \\
(0.00-0.00)\end{array}$ & 13/192 & $\begin{array}{l}6.8 \\
(3.24-10.36)\end{array}$ & $.04^{*}$ & $13 / 251$ & $\begin{array}{l}5.2 \\
(2.45-7.95)\end{array}$ \\
\hline Surgery & $0 / 59$ & $\begin{array}{l}0.0 \\
(0.00-0.00)\end{array}$ & 3/192 & $\begin{array}{l}1.6 \\
(0.00-3.37)\end{array}$ & $1.00^{*}$ & $3 / 251$ & $\begin{array}{l}1.2 \\
(0.00-2.55)\end{array}$ \\
\hline Occupational injury & $0 / 59$ & $\begin{array}{l}0.0 \\
(0.00-0.00)\end{array}$ & $3 / 192$ & $\begin{array}{l}1.6 \\
(0.00-3.37)\end{array}$ & $1.00^{*}$ & $3 / 251$ & $\begin{array}{l}1.2 \\
(0.00-2.55)\end{array}$ \\
\hline
\end{tabular}


Table 5. HBeAg/anti-HBe pattern in non-Italian and Italian HBsAg positive patients adjusting for age and gender

\begin{tabular}{|c|c|c|c|c|c|c|c|}
\hline \multirow[b]{2}{*}{ Total cases } & \multicolumn{2}{|c|}{ Non-Italian } & \multicolumn{2}{|l|}{ Italian } & \multirow[t]{2}{*}{$\mathbf{p}$} & \multicolumn{2}{|l|}{ Total } \\
\hline & $\mathbf{N}$ & $\begin{array}{l}\% \\
(95 \% \mathrm{Cl})\end{array}$ & $\mathbf{N}$ & $\begin{array}{l}\% \\
(95 \% \mathrm{Cl})\end{array}$ & & $\mathbf{N}$ & $\begin{array}{l}\% \\
(95 \% \mathrm{Cl})\end{array}$ \\
\hline $\mathrm{HBeAg}+/$ anti-HBe- & $5 / 84$ & $\begin{array}{l}6.0 \\
(0.92-11.08)\end{array}$ & $24 / 267$ & $\begin{array}{l}9.0 \\
(5.57-12.43)\end{array}$ & .28 & $29 / 351$ & $\begin{array}{l}8.3 \\
(5.41-11.19)\end{array}$ \\
\hline HBeAg-/anti-HBe+ & $79 / 84$ & $\begin{array}{l}94.0 \\
(88.92-99.08)\end{array}$ & $237 / 267$ & $\begin{array}{l}88.8 \\
(85.02-92.58)\end{array}$ & .09 & $316 / 351$ & $\begin{array}{l}90.0 \\
(86.86-93.14)\end{array}$ \\
\hline Other profiles* & $0 / 84$ & $\begin{array}{l}0.0 \% \\
(0.00-0.00)\end{array}$ & $6 / 267$ & $\begin{array}{l}2.2 \% \\
(0.44-3.96)\end{array}$ & $.34^{* *}$ & $6 / 351$ & $\begin{array}{l}1.7 \% \\
(0.35-3.05)\end{array}$ \\
\hline Incident cases & & & & & & & \\
\hline $\mathrm{HBeAg}+/$ anti-HBe- & $3 / 35$ & $\begin{array}{l}8.6 \\
(0.00-17.89)\end{array}$ & $2 / 40$ & $\begin{array}{l}5.0 \\
(0.00-11.75)\end{array}$ & .82 & $5 / 75$ & $\begin{array}{l}6.7 \\
(1.04-12.36)\end{array}$ \\
\hline $\mathrm{HBeAg}$-/anti-HBe+ & $32 / 35$ & $\begin{array}{l}91.4 \\
(82.11-100)\end{array}$ & $38 / 40$ & $\begin{array}{l}95.0 \\
(88.25-100) \\
\end{array}$ & .82 & $70 / 75$ & $\begin{array}{l}93.3 \\
(87.64-98.96) \\
\end{array}$ \\
\hline
\end{tabular}


Stratified by geographic area, the only significant differences in incident case were identified for subjects from China and the Far East: prevalence of $\mathrm{HBeAg}$ cases higher than Italian subjects: $40 \%, 95 \% \mathrm{Cl}: 0.00-82.94, \mathrm{p}=.03)$.

The results of searches for $\mathrm{HBeAg}$ and anti-HBe were available for 351 patients, 74 of whom were incident cases. There were no statistically significant differences between the Italian and the total non-Italian patients (adjusting for age and gender) (Table 5). Stratified by geographic area, the only significant differences in incident case were identified for subjects from China and the Far East: prevalence of $\mathrm{HBeAg}$ cases higher than Italian subjects: $40 \%$, 95\% Cl: 0.00-82.94, $\mathrm{p}=.03$ ).

\section{DISCUSSION}

The recent increase in immigration in Italy has led to a growing number of residents from countries in which HBV is more endemic. Consequently, the epidemiology of HBV in Italy is rapidly changing and its clinical impact needs to be evaluated. In the present study, about a quarter of all of the HBsAg-positive subjects tested at our hospital were non-Italians. As reported by Eurostat 2008, most of these came from Eastern Europe, fewer from subSaharan Africa, China/Far East, the Middle East/Maghreb, and even fewer from the Indian sub-continent, North and South America, and Western Europe. Sub-Saharan Africa, part of China and Far East are areas with $8-20 \%$ of HBsAg prevalence and Eastern Europe and some area of Middle East/Maghreb are areas with 2-7\% of prevalence so it is expected that immigrant subjects from these countries can mainly contribute to the increase in total prevalence in Italy that is now considered a country with low prevalence. Subjects coming from low prevalence as America and Western Europe do not affect the total prevalence, but, in our study, these groups were very small and so very little can be further said about them.

It must also be borne in mind that, although we examined the records of all of the patients who were HBsAg positive during the period under study, only those followed by the Italian health service come to our clinical observation (and therefore only immigrants with a degree of economic integration under lawful conditions). Some immigrants refuse contact with public health services for fear of expulsion or because they have specific cultural, religious or psychological attitudes towards medical practices [37], and therefore can be considered the hidden part of the HBV "iceberg" [38].

In general, the non-Italians in this study were mainly women and younger than their Italian counterparts, but this varied on the basis of their geographic area of origin: the subjects from the Far East and Eastern Europe (the largest group) were mainly women, but not those from other areas; and the age of the Western European and American subjects was more similar to that of the Italians than that of the other groups. In terms of presentation, the main differences from the Italians primarily concerned clinical conditions, the time of diagnosis, and risk factors. The non-Italians were mainly recently diagnosed (in line with their recent arrival in Italy), and this is also true for the subjects from Eastern Europe, China/Far East and Indian subcontinent. Among the more numerous groups, the patients were predominantly asymptomatic and probably considered themselves healthy and fit to emigrate.

The no differences in the prevalence of chronic HBeAg-positive infections between the Italian and non-Italian patients (except for the cases from China and the Far East, but they are very few and this can reflect the different HBeAg infection in different countries) can support the data, as reported by other studies, that the Mediterranean variant is widespread 
in geographic areas in which it was once rarer [30-32]. This was even seen in the chronic incident cases which, given the unsure dating of infection, might be a more appropriate approximate index of untreated infection. On the other hand, the low number of non-Italian $\mathrm{HBeAg}$ negative patients may be due to the high number of asymptomatic and, as expected, $\mathrm{HBeAg}$ negative subjects. However, as this was a retrospective study, we could not test for HBV genotypes or any mutations.

Also the no differences between Italians and non-Italians in terms of the presence of anti$\mathrm{HCV}$, anti-HDV antibodies, suggests that the rate of co-infections is similar among the two groups. In terms of known risk factors, the most important difference concerned vertical/perinatal transmission, which is still an important risk factor particularly for the more numerous groups and may reflect the epidemiological situation in the patients' countries of origin.

\section{CONCLUSION}

The recent increase in immigration to Italy has led to the arrival a growing number of patients from countries in which HBV is more endemic, who therefore represent a reservoir for new HBV infection (in our case, they accounted for about one-fifth of all subjects). On the other hand, most of them present asymptomatic infection, thus indicating that their clinical impact is currently limited. However, migrants are heterogeneous and come from different socioeconomic backgrounds with different healthcare histories [39], and so possible changes in their composition may further change the clinical impact of HBV infection. Given the continuous increase in the flow of immigration, continuous monitoring may be useful in order to prepare for what this might bring.

\section{COMPETING INTERESTS}

Authors have declared that no competing interests exist.

\section{REFERENCES}

1. Goldstein ST, Zhou F, Hadler SC, Bell BP, Mast EE, Margolis HS. A mathematical model to estimate global hepatitis $B$ disease burden and vaccination impact. Int $\mathrm{J}$ Epidemiol. 2005;34:1329-39.

2. Lavanchy D. Worldwide epidemiology of HBV infection, disease burden, and vaccine prevention. J Clin Virol. 2005;34(Suppl 1):S1-3.

3. $\quad$ Lee WM. Hepatitis B virus infection. N Engl J Med. 1997;337:1733-45.

4. Shepard CW, Simard EP, Finelli L, Fiore AE, Bell BP. Hepatitis B virus infection: epidemiology and vaccination. Epidemiol Rev. 2006;28:112-25.

5. World Health Organization. Hepatitis B Fact Sheet No 204 (Revised October 2008). (http://who.int/mediacentre/factsheets/fs204/en).

6. World Health Organization. Hepatitis B vaccines- making global progress. In: Update, Expanded Programme on Immunization. WHO, 1996.

7. Giusti G, Galanti B, Gaeta GB. Epidemiology of viral hepatitis in Italy. Boll Ist Sieroter Milan. 1980;59:571-80.

8. Giusti G, Galanti B, Gaeta GB, Piccinino F, Ruggiero G. HBsAg carriers among blood donors in Italy; a retrospective survey of data from 189 blood banks. Hepatogastroenterology. 1981;28:96-8. 
9. Pasquini $P$, Kahn HA, Pileggi D, Panà A, Terzi J, Guzzanti E. Prevalence of hepatitis B markers in Italy. Am J Epidemiol. 1983;118:699-709.

10. Romanò L, Paladini S, Tagliacarne C, Zappa A, Zanetti AR. The changing face of the epidemiology of type A, B, and D viral hepatitis in Italy, following the implementation of vaccination. Vaccine. 2009;27:3439-42.

11. Piazza M, Da Villa G, Picciotto L, Abrescia N, Guadagnino V, Memoli AM, et al. Mass vaccination against hepatitis $B$ in infants in Italy. Lancet. 1988;2:1132.

12. Zanetti AR, Tanzi E, Romanò L, Grappasonni I. Vaccination against hepatitis B: the Italian strategy. Vaccine. 1993;11:521-4.

13. Stroffolini T, Mele A, Tosti ME, Gallo G, Balocchini E, Ragni P, et al. The impact of the hepatitis $B$ mass immunisation campaign on the incidence and risk factors of acute hepatitis B in Italy. J Hepatol. 2000;33:980-985.

14. Mele A, Tosti ME, Mariano A, Pizzuti R, Ferro A, Borrini B, and The National Surveillance System for Acute Viral Hepatitis (SEIEVA) Collaborating Group. Acute hepatitis B 14 years after the implementation of universal vaccination in Italy: areas of improvement and emerging challenges. Clin Infect Dis. 2008;46:868-75.

15. Stroffolini $T$. The changing pattern of hepatitis $B$ virus infection over the past three decades in Italy. Dig Liver Dis. 2005;37:622-7.

16. Tafuri S, Prato R, Martinelli D, Melpignano L, De Palma M, Quarto M, Germinario C. Prevalence of Hepatitis B, C, HIV and syphilis markers among refugees in Bari, Italy. BMC Infect Dis. 2010;10:213.

17. Caritas migrantes: Immigrazione Dossier Statistico 2008 XVIII rapporto. Edizioni Idos Roma 2008. Italian.

18. De Paschale M, Manco MT, Belvisi L, Magnani $\mathrm{C}$, Re $\mathrm{T}$, Viganò $\mathrm{P}$, et al. How immigration can change the prevalence of HBV infection in an urban area of Northern Italy. Microbiology Research. 2011;2:e21.

19. Chu CJ, Lok AS. Clinical significance of hepatitis B virus genotypes. Hepatology. 2002;35: 1274-6.

20. Dal Molin G, Poli A, Crocè LS, D'Agaro P, Biagi C, Comar M, et al. Hepatitis B virus genotypes, core promoter variants, and precore stop codon variants in patients infected chronically in North-Eastern Italy. J Med Virol. 2006;78:734-40.

21. Deterding K, Constantinescu I, Nedelcu FD, Gervain J, Nemecek V, Srtunecky O, et al. Prevalence of HBV genotypes in Central and Eastern Europe. J Med Virol. 2008;80:1707-11.

22. Flink HJ, van Zonneveld M, Hansen BE, de Man RA, Schalm SW, Janssen HL, and The HBV 99-01 Study Group. Treatment with Peg-interferon alpha-2b for HBeAgpositive chronic hepatitis B: HBsAg loss is associated with HBV genotype. Am J Gastroenterol. 2006;101:297-303.

23. Kao JH. Hepatitis B viral genotypes: clinical relevance and molecular characteristics. J Gastroenterol Hepatol. 2002;17:643-50.

24. Mahtab MA, Rahman S, Khan M, Karim F. Hepatitis B virus genotypes: an overview. Hepatobiliary Pancreat Dis Int. 2008;7:457-64.

25. Miyakawa Y, Mizokami M. Classifying hepatitis B virus genotypes. Intervirology. 2003;46:329-38.

26. Sumi H, Yokosuka O, Seki N, Arai M, Imazeki F, Kurihara T, et al. Influence of hepatitis $\mathrm{B}$ virus genotypes on the progression of chronic type $\mathrm{B}$ liver disease. Hepatology. 2003;37:19-26.

27. Tseng TC, Kao JH. HBV genotype and clinical outcome of chronic hepatitis B: facts and puzzles. Gastroenterology. 2008;134:1272-3. 
28. Yuen MF, Tanaka Y, Shinkai N, Poon RT, But DY, Fong DY, et al. Risk for hepatocellular carcinoma with respect to hepatitis $B$ virus genotypes $B / C$, specific mutations of enhancer II/core promoter/precore regions and HBV DNA levels. Gut. 2008;57:98-102.

29. Hadziyannis SJ. Hepatitis B e antigen negative chronic hepatitis B. From clinical recognition to pathogenesis and treatment. Viral Hep Rev. 1995;1:7-36.

30. Funk ML, Rosenberg DM, Lok AS. World-wide epidemiology of HBeAg-negative chronic hepatitis $B$ and associated precore and core promoter variants. J Viral Hepat. 2002;9:52-61.

31. Gaeta GB, Stroffolini T, Smedile A, Niro G, Mele A. Hepatitis delta in Europe: vanishing or refreshing? Hepatology. 2007;46:1312-3.

32. Sagnelli E, Stroffolini T, Mele A, Imparato M, Almasio PL, and The Italian Hospitals' Collaborating Group. Chronic hepatitis B in Italy: new features of an old disease-approaching the universal prevalence of hepatitis $B$ e antigen-negative cases and the eradication of hepatitis D infection. Clin Infect Dis. 2008;46:110-3.

33. Stroffolini T, Almasio PL, Sagnelli E, Mele A, Gaeta GB, and The Italian Hospitals' Collaborating Group. Evolving clinical landscape of chronic hepatitis B: A multicenter Italian study. J Med Virol. 2009;81:1999-2006.

34. Gaiani S, Gramantieri L, Venturoli N, Piscaglia F, Siringo S, D'Errico A, et al. What is the criterion for differentiating chronic hepatitis from compensated cirrhosis? A prospective study comparing ultrasonography and percutaneous liver biopsy. J Hepatol. 1997;27:979-85.

35. Bruix J, Sherman M, and The American Association for the Study of Liver Diseases. Management of hepatocellular carcinoma: an update. Hepatology. 2011;53:1020-2.

36. Villa E, Fattovich G, Mauro A, Pasino M. Natural history of chronic HBV infection: special emphasis on the prognostic implications of the inactive carrier state versus chronic hepatitis. Dig Liver Dis. 2011;43(Suppl 1):S8-14.

37. van der Veen YJ, de Zwart O, Voeten HA, Mackenbach JP, Richardus JH. Hepatitis B screening in the Turkish-Dutch population in Rotterdam, the Netherlands; qualitative assessment of socio-cultural determinants. BMC Public Health. 2009;9:328.

38. Torre F, Basso M, Giannini EG, Feasi M, Boni S, Grasso A, et al. Clinical and virological survey of patients with hepatitis $B$ surface antigen in an Italian region: clinical considerations and disease burden. J Med Virol. 2009;81:1882-6.

39. Carballo M, Cody R, O’Relly E. Migration, Hepatitis B and hepatitis C. International Centre for Migration Health and Development. Accessed 20 July 2012.

Available: http://www.helpbcppa.org/wp-content/uploads/2011/Migration-report.pdf.

(C) 2013 Paschale et al.; This is an Open Access article distributed under the terms of the Creative Commons Attribution License (http://creativecommons.org/licenses/by/3.0), which permits unrestricted use, distribution, and reproduction in any medium, provided the original work is properly cited.

Peer-review history:

The peer review history for this paper can be accessed here: http://www.sciencedomain.org/review-history.php?iid=163\&id=12\&aid=749 